\title{
Effects of Staphylococcus aureus Bacteriophage K on Expression of Cytokines and Activation Markers by Human Dendritic Cells In Vitro
}

\author{
Helen R. Freyberger, Yunxiu He, Amanda L. Roth ${ }^{\dagger}$, Mikeljon P. Nikolich \\ and Andrey A. Filippov * \\ Department of Bacteriophage Therapeutics, Bacterial Diseases Branch, Walter Reed Army Institute of Research, \\ Silver Spring, MD 20910, USA; helen.r.freyberger.ctr@mail.mil (H.R.F.); yunxiu.he.ctr@mail.mil (Y.H.); \\ amanda.l.roth.mil@mail.mil (A.L.R); mikeljon.p.nikolich.civ@mail.mil (M.P.N.) \\ * Correspondence: andrey.a.filippov.ctr@mail.mil; Tel.: +1-301-319-9962 \\ + Current address: Pharmaceutical Systems, US Army Medical Materiel Development Activity, \\ Fort Detrick, MD 21702, USA.
}

Received: 29 September 2018; Accepted: 6 November 2018; Published: 8 November 2018

check for updates

\begin{abstract}
A potential concern with bacteriophage (phage) therapeutics is a host-versus-phage response in which the immune system may neutralize or destroy phage particles and thus impair therapeutic efficacy, or a strong inflammatory response to repeated phage exposure might endanger the patient. Current literature is discrepant with regard to the nature and magnitude of innate and adaptive immune response to phages. The purpose of this work was to study the potential effects of Staphylococcus aureus phage K on the activation of human monocyte-derived dendritic cells. Since phage K acquired from ATCC was isolated around 90 years ago, we first tested its activity against a panel of 36 diverse $S$. aureus clinical isolates from military patients and found that it was lytic against 30/36 (83\%) of strains. Human monocyte-derived dendritic cells were used to test for an in vitro phage-specific inflammatory response. Repeated experiments demonstrated that phage $\mathrm{K}$ had little impact on the expression of pro- and anti-inflammatory cytokines, or on MHC-I/II and CD80/CD86 protein expression. Given that dendritic cells are potent antigen-presenting cells and messengers between the innate and the adaptive immune systems, our results suggest that phage $\mathrm{K}$ does not independently affect cellular immunity or has a very limited impact on it.
\end{abstract}

Keywords: Staphylococcus aureus; bacteriophage K; human dendritic cells; cytokines and activation markers

\section{Introduction}

Staphylococcus aureus is a leading cause of human bacteremia, infective endocarditis, osteoarticular, skin and soft tissue, pleuropulmonary, and device-related infections [1]. Clinical isolates of $S$. aureus demonstrate frequent multidrug resistance, the most important of which is methicillin and vancomycin resistance [2]. Formation of mature biofilms increases $S$. aureus persistence in tissues and medical implants and causes additional antibiotic tolerance [3]. The prevalence of multidrug-resistant S. aureus infections leaves physicians with limited options for antibacterial therapy and demands new therapies with current interest focused on bacteriophages (phages). Phages have shown efficacy against experimental $S$. aureus infections using several animal models, as well as promising results in humans [4].

There is a reasonable concern about the immunogenicity of phages and whether it could impact their in vivo efficacy [5-7]. Conflicting data on phage immunomodulatory properties, including their effects on inflammation, interactions with phagocytes, $\mathrm{T}$ and $\mathrm{B}$ cells, the fate of phage inside phagocytes, phage intracellular activity, cytokine stimulation, induction of antibody production, phage-neutralizing 
effects of the antibodies, and the impacts of phage immunogenicity on their therapeutic efficacy have made it difficult to interpret and draw overarching conclusions about the true impact of phage therapy (for reviews, see References [8-10]). For example, a recent publication described a marked stimulation of pro-inflammatory cytokines released by human PBMC and immortalized cell lines HT-29 and Caco-2 following exposure to four different Escherichia coli phages [11]. In fact, the levels of cytokines IL-6 and TNF $\alpha$ in phage-treated samples were comparable to those observed in the samples treated with lipopolysaccharide (LPS). These unusual results raised the question about whether possible insufficient purification of the phage preparations and LPS contamination compromised the interpretation of the data [12].

In contrasting studies, there was a complete lack of cytokine response to phage treatment. For example, enterobacteriophage T4 or its head proteins had no effect on the production of inflammatory mediators and inflammation-related factors including IL-1 $\alpha$, IL-1 $\beta$, IL-2, IL-6, IL-10, IL-12 p40/p70, IFN- $\gamma$, TNF $\alpha$, MCP-1, MIG, etc. using both human blood cells in vitro and an in vivo mouse model [13]. After oral administration of three E. coli O157:H7 phages to mice, all cytokine levels remained within normal ranges [14]. Purified phages T4 and A3/ $R$ had no effect on differentiation of human dendritic cells while crude phage lysates significantly reduced the expression of markers associated with differentiation [15]. Interestingly, mouse dendritic cells exposed to phage T4 had enhanced anti-tumor effect [16].

Several publications indicate that phages may have potent anti-inflammatory effects. For example, phages reduced cellular infiltration of mouse skin transplants and the levels of pro-inflammatory factor NF-кB [7]. Phage therapy in humans resulted in a dramatic reduction of $C$ reactive protein values and leukocyte counts, which was unparalleled by a reduction in live bacteria counts [17]. Phage T4 tail protein gp12 identified as a receptor-binding protein was demonstrated to bind LPS and reduce LPS-induced inflammation in mice [18]. Another team observed the reduction of S. aureus-mediated expression of inflammatory cytokines in mice caused by phage SLPW [19].

Current literature provides evidence that even phages that target the same bacterial pathogen may yield different effects. Shiley et al. [20] have recently used a human lung in vitro model and observed a phage PEV2-mediated increase in IL-6 and TNF $\alpha$ production, yet another Pseudomonas aeruginosa phage, DMS3, did not change the levels of these cytokines. It was found that even the same phage may or may not induce inflammatory response depending on the approach used. Commercially available $S$. aureus phage SATA-8505 did not induce inflammatory responses in peripheral blood mononuclear cells (PBMC) but did induce IFN- $\gamma$ production in primary keratinocyte cultures and elicited inflammatory responses in mice [21].

It was demonstrated that some phages can be ingested by phagocytes $[22,23]$ but there are conflicting data on phage influence on phagocytosis of bacteria and intracellular bacterial lysis by phage. Phage therapy against different infections did not affect the ability of patients' peripheral blood monocytes and polymorphonuclear neutrophils to kill E. coli, Enterococcus faecalis, P. aeruginosa or S. aureus [24]. Acceleration of turnover of circulating neutrophils but a decrease in their bactericidal activity was observed in patients who received phage against suppurative $S$. aureus infections [25]. In another study, increased phagocytosis by neutrophils was noted in patients with successful results of phage therapy [8]. In a recent work, Roach et al. [26] observed a neutrophil-phage synergy that was important for resolution of P. aeruginosa pneumonia in mice treated with phage PAK_P1: Mice depleted of their neutrophils were completely unresponsive to inhaled phage treatment.

Some phages are capable of penetrating phagocytes to kill internalized bacteria. An S. aureus phage MSa could penetrate into murine macrophages (but only using S. aureus cells as a carrier) and destroy the bacteria inside macrophages [27]. On the contrary, bacteriophage TM4 did not show the ability to be phagocytosed by macrophages and to kill intracellular Mycobacterium tuberculosis and Mycobacterium avium, though another phage, D29, was able to enter macrophages and kill the mycobacteria inside them [28]. Our previous data suggest that phage $\varphi$ A1122 is not able to get inside 
mouse macrophages either alone or using Yersinia pestis cells as a carrier and thus cannot kill the bacteria inside macrophages [29].

Investigative work on the relationship between the adaptive immune response and phages is also inconsistent. In some cases, phage-neutralizing antibodies were found in patient sera even before phage administration, suggesting pre-exposure to a common phage antigen or epitope found in the environment [8]. However, the titers of preexisting antibodies were as low as 1:10-1:100, while the local administration of phage resulted in much higher titers, up to 1:1500 [8]. Surprisingly, not only antibodies to T4 tail proteins that occlude the receptor-binding part of the phage caused phage inactivation, but also anti-head immunization reduced phage activity [30]. Interestingly, no antibody response was observed in volunteers who received T4 phage orally [31] and very low titers of phage-neutralizing antibodies were found in patients after multiple oral administrations of a therapeutic phage [8,32]. Anti-phage activity of sera of patients that received phage therapy also depended on phage type and did not impact the therapeutic outcome [32-34].

Thus multiple publications have shown different innate and adaptive immunity responses to phages, which requires additional studies on their immunomodulatory properties. The purpose of this work was to investigate effects of $S$. aureus phage K on activation of human monocyte-derived dendritic cells. Two experiments using different batches of human CD14+ monocytes showed that the $\mathrm{K}$ phage had very limited impact on the expression of pro- and anti-inflammatory cytokines, or activation factors. Since dendritic cells capture, process and present antigens to T cells and thus link the innate and adaptive immune systems, our data may indicate that $S$. aureus phage $\mathrm{K}$ has limited to no effect on cellular immunity.

\section{Materials and Methods}

\subsection{Bacterial Strains and Media}

S. aureus strains used in this work are described in Table 1. The cultures were grown in liquid Heart Infusion Broth (HIB) or on plates of 1.5\% HIB agar (BD: Becton, Dickinson and Co., Franklin Lakes, NJ, USA). For phage plating, $0.7 \%$ semisolid HIB agar was overlaid on $1.5 \%$ HIB agar.

\subsection{Bacteriophage Propagation and Purification}

Phage K was purchased from the American Type Culture Collection (ATCC, Manassas, VA, USA). The phage was propagated on S. aureus NSCO308 (Table 1). Four milliliters of overnight bacterial culture was added to $400 \mathrm{~mL}$ of HIB in a 2-L flask and incubated at $37^{\circ} \mathrm{C}$ with shaking at $200 \mathrm{rpm}$ until the optical density at $600 \mathrm{~nm}$ (OD600) became 0.1-0.2 (ca. 10 $\mathrm{CFU} / \mathrm{mL}$ ) that corresponds mid-log phase of the culture growth. The phage was added at a multiplicity of infection (MOI) of 0.1 , the culture was thoroughly but carefully mixed, and phage was allowed to adsorb for $15 \mathrm{~min}$ at $37^{\circ} \mathrm{C}$ without shaking. The mix was incubated at $37^{\circ} \mathrm{C}$ and $100 \mathrm{rpm}$ for at least $4 \mathrm{~h}$ with periodical measuring of OD600 until it dropped to 0.05 or less. Sodium chloride powder was added to $1 \mathrm{M}$, gently solved on a rocking platform; the lysate was incubated in an ice bath for one hour and centrifuged for $10 \mathrm{~min}$ at $4{ }^{\circ} \mathrm{C}$ and $11,000 \times g$ to remove the bacterial debris. PEG 8000 was added to the supernatant up to $10 \%(w / v)$, dissolved on a rocking platform and the mix was incubated in an ice bath for one hour. Phage particles were precipitated by centrifugation for $10 \mathrm{~min}$ at $4{ }^{\circ} \mathrm{C}$ and $11,000 \times g$ in two separate tubes and the supernatant was removed. The pellets were dried for $5 \mathrm{~min}$ at room temperature; one of them was resuspended in $3 \mathrm{~mL}$ of SM buffer (Teknova, Hollister, CA, USA), filter sterilized using a sterile $0.22-\mu \mathrm{m}$ membrane, aliquoted in freeze vials, wrapped with aluminum foil and stored at $4{ }^{\circ} \mathrm{C}$ (phage stock for long storage). Another pellet was resuspended in phosphate-buffered saline (PBS, Gibco, Gaithersburg, MD, USA) and split into two parts, both for studies with human dendritic cells. One part was filter sterilized and stored at $4{ }^{\circ} \mathrm{C}$. The second part of phage suspension in PBS was placed in Spectra/Por DispoDialyzers (MWCO $=15,000$, Repligen Corporation, Waltham, MA, USA), dialyzed overnight at $4{ }^{\circ} \mathrm{C}$ against $1 \mathrm{~L}$ of PBS, then filter sterilized and stored at $4{ }^{\circ} \mathrm{C}$. 
Table 1. S. aureus strains used in this work.

\begin{tabular}{|c|c|c|c|c|c|c|}
\hline Strain & Source & $\begin{array}{c}\text { Tissue/Organ } \\
\text { of Origin }\end{array}$ & $\begin{array}{l}\text { MSSA or } \\
\text { MRSA }^{1}\end{array}$ & $\begin{array}{c}\text { Phage K } \\
\text { Susceptibility }^{2}\end{array}$ & $\begin{array}{l}\text { Phage K Titer } \\
\text { (PFU/mL) }\end{array}$ & $\begin{array}{c}\text { Phage K } \\
\text { EOP }^{3}\end{array}$ \\
\hline NSCO308 & $\mathrm{WID}^{4}$ & $\mathrm{UNK}^{5}$ & MSSA & S & $6.0 \times 10^{11}$ & 1.00 \\
\hline MRSN18 & MRSN $^{6}$ & Wound & MRSA & S & $3.0 \times 10^{11}$ & 0.50 \\
\hline MRSN30 & MRSN & Wound & MRSA & S & $8.0 \times 10^{10}$ & 0.13 \\
\hline MRSN42 & MRSN & Wound & MRSA & S & $2.5 \times 10^{11}$ & 0.42 \\
\hline MRSN214 & MRSN & Wound & MRSA & S & $2.5 \times 10^{10}$ & 0.04 \\
\hline MRSN219 & MRSN & Urine & MRSA & S & $2.0 \times 10^{11}$ & 0.33 \\
\hline MRSN250 & MRSN & Urine & MRSA & S & $1.5 \times 10^{11}$ & 0.25 \\
\hline MRSN352 & MRSN & Wound & MRSA & S & $2.5 \times 10^{11}$ & 0.42 \\
\hline MRSN549 & MRSN & Wound & MRSA & S & $2.5 \times 10^{11}$ & 0.42 \\
\hline MRSN563 & MRSN & Wound & MRSA & S & $2.2 \times 10^{11}$ & 0.37 \\
\hline MRSN1722 & MRSN & Sputum & MRSA & S & $1.3 \times 10^{10}$ & 0.02 \\
\hline MRSN1732 & MRSN & Tissue & MRSA & S & $4.5 \times 10^{11}$ & 0.75 \\
\hline MRSN1952 & MRSN & Wound & MRSA & S & $1.0 \times 10^{11}$ & 0.17 \\
\hline MRSN2339 & MRSN & Wound & MRSA & S & $2.5 \times 10^{10}$ & 0.04 \\
\hline MRSN2763 & MRSN & Wound & MRSA & $\mathrm{S}$ & $9.5 \times 10^{10}$ & 0.16 \\
\hline MRSN3573 & MRSN & Blood & MRSA & $\mathrm{R}$ & 0 & 0 \\
\hline MRSN3643 & MRSN & Tissue & MRSA & S & $1.3 \times 10^{11}$ & 0.22 \\
\hline MRSN3710 & MRSN & Wound & MRSA & S & $3.0 \times 10^{11}$ & 0.50 \\
\hline MRSN3966 & MRSN & Blood & MRSA & $\mathrm{R}$ & 0 & 0 \\
\hline MRSN4109 & MRSN & Sputum & MRSA & S & $6.0 \times 10^{10}$ & 0.10 \\
\hline MRSN4344 & MRSN & Wound & MSSA & S & $2.0 \times 10^{11}$ & 0.33 \\
\hline MRSN4531 & MRSN & Wound & MRSA & S & $4.0 \times 10^{11}$ & 0.67 \\
\hline MRSN4535 & MRSN & Wound & MRSA & S & $8.0 \times 10^{10}$ & 0.13 \\
\hline MRSN5079 & MRSN & Wound & MSSA & S & $2.0 \times 10^{11}$ & 0.33 \\
\hline MRSN6168 & MRSN & Blood & MSSA & $\mathrm{R}$ & 0 & 0 \\
\hline MRSN7983 & MRSN & Wound & MSSA & S & $1.5 \times 10^{11}$ & 0.25 \\
\hline MRSN8383 & MRSN & Wound & MSSA & S & $2.0 \times 10^{11}$ & 0.33 \\
\hline MRSN9127 & MRSN & Sputum & MSSA & S & $1.5 \times 10^{11}$ & 0.25 \\
\hline MRSN9287 & MRSN & Wound & MSSA & $\mathrm{R}$ & 0 & 0 \\
\hline MRSN9832 & MRSN & Nasal swab & MRSA & $\mathrm{R}$ & 0 & 0 \\
\hline MRSN9834 & MRSN & Nasal swab & MRSA & S & $4.0 \times 10^{10}$ & 0.07 \\
\hline MRSN10110 & MRSN & Wound & MSSA & S & $1.1 \times 10^{11}$ & 0.18 \\
\hline MRSN10185 & MRSN & Blood & MSSA & $S$ & $7.5 \times 10^{10}$ & 0.12 \\
\hline MRSN12239 & MRSN & Eye & MSSA & S & $9.5 \times 10^{11}$ & 1.58 \\
\hline NAJAF22 & MRSN & UNK & MRSA & S & $1.2 \times 10^{11}$ & 0.20 \\
\hline NAJAF33 & MRSN & UNK & MRSA & $\mathrm{R}$ & 0 & 0 \\
\hline
\end{tabular}

${ }^{1}$ MSSA, methicillin-susceptible S. aureus; MRSA, methicillin-resistant S. aureus. ${ }^{2}$ S, susceptible; R, resistant. ${ }^{3}$ EOP, efficiency of plating. ${ }^{4}$ Wound Infection Department, Bacterial Diseases Branch, Walter Reed Army Institute of Research. ${ }^{5}$ UNK, unknown. ${ }^{6}$ Multidrug-resistant Organism Repository and Surveillance Network, Bacterial Diseases Branch, Walter Reed Army Institute of Research.

\subsection{Phage Efficiency of Plating (EOP) Tests}

Five-milliliter aliquots of melted $0.7 \%$ HIB agar were cooled down to $47^{\circ} \mathrm{C}$, mixed with $0.1 \mathrm{~mL}$ of overnight culture of each tested S. aureus strain, overlaid on $1.5 \%$ HIB agar plates and left to solidify for $5 \mathrm{~min}$ at room temperature with half-open lids. Serial 10-fold dilutions of the phage K SM buffer stock from $10^{-1}$ to $10^{-8}$ were prepared in SM buffer using a sterile 96-well flat-bottom plate, and $2 \mu \mathrm{L}$ of each dilution were spotted on the top agar with an 8-channel pipette. The drops were allowed to dry, the plates were flipped and incubated overnight at $37^{\circ} \mathrm{C}$. Plaques were counted and phage titers were calculated for each strain. The titer obtained on the propagation strain (NSCO308) was taken for the efficiency of plating $=1$ and EOPs for the rest of the strains were calculated by dividing phage $\mathrm{K}$ titers on them into the titer on NSCO308. S. aureus culture was considered as phage-susceptible when the phage was able to form isolated plaques from the highest dilutions (i.e., productive phage infection was observed), and the absence of plaquing was considered as phage resistance. 


\subsection{Monocyte-Derived Dendritic Cells}

Primary human CD14+ monocytes were purchased from ATCC. Dendritic Cell Differentiation Kits (R\&D Systems, Minneapolis, MN, USA) were used according to kit directions to convert the monocytes to immature monocyte-derived dendritic cells. Briefly, cells were plated in 24-well plates at $10^{6}$ cells/mL in "differentiation medium" from the kit containing IL-4 and GM-CSF with half-volume medium changes on days 3, 5 and 7. On day 7, cells were treated with either positive control "activation medium" containing tumor necrosis factor (TNF), phage-treated medium containing phage $\mathrm{K}$ at a final concentration of $10^{8} \mathrm{PFU} / \mathrm{mL}$ (100 PFU/cell), or negative control medium with a volume of PBS equal to that of the phage preparation. At $24 \mathrm{~h}$ intervals after treatment, triplicate sample wells were collected by pipetting off medium into a separate tube, briefly centrifuging to remove cellular debris, and freezing aliquots at $-80{ }^{\circ} \mathrm{C}$ for later analysis. Cells were rinsed with PBS, resuspended with TrypLE Express (Gibco), rinsed again with PBS, and fixed in 4\% formalin in PBS for 10 min in a shaking incubator at $37^{\circ} \mathrm{C}$. Cells were rinsed twice with PBS, resuspended in PBS and stored at $4{ }^{\circ} \mathrm{C}$ until analysis. Dendritic cell phenotype was confirmed by staining for CD11c and CD209 during analysis.

\subsection{Flow Cytometry}

Formalin-fixed cell samples were suspended in staining buffer $(10 \%$ fetal bovine serum in PBS). Samples were treated with Fc block, then stained with either staining buffer including APC-labeled anti-CD209 (BD), BV421-labeled anti-CD80 (BD), PerCP-Cy5.5-labeled anti-CD11c (BD), PE-Cy7-labeled anti-CD86 (BD), FITC labeled anti-MHC I HLA-ABC (Invitrogen, Carlsbad, CA, USA), and PE-labeled anti-MHC II HLA-DP/DQ/DR (Invitrogen) or a staining control buffer including dye-matched isotype control antibodies (BD and Invitrogen). Cells were incubated at room temperature for $1 \mathrm{~h}$, rinsed with staining buffer, and resuspended in PBS. Samples were read on a FACS Canto II flow cytometer (BD).

\subsection{Bead-Based Immunoassays}

Supernatant cytokine concentrations were measured using bead-based immunoassays for human IL-1 $\beta$, IL-2, IL-6, IL-8, IL-10, IL-12p70, IFN- $\gamma$, RANTES, and MCP-1 (BD) according to manufacturer's instructions. Bead fluorescence levels were read on a FACSCanto II flow cytometer. Cytokine concentrations were calculated by fitting a 4-parameter logistic curve to cytokine standards included in the kits and applying this formula to sample fluorescence readings.

\subsection{Statistics}

Two-way ANOVA with interaction between treatment group and day of collection was conducted with Statistical Analysis System (SAS: SAS Institute, Cary, NC, USA). Multiple comparison of least square means adjusted with the Tukey approach were performed separately for data from each day. Pairwise Welch's $t$-tests were also performed between samples. $\alpha$ for these $t$-tests was determined with a Bonferroni correction for each experiment.

\section{Results}

\subsection{Phage K Host Ranges on Military Clinical Isolates}

Bacteriophage K purchased from ATCC was isolated as early as 1930 [35]. Before testing its effects on human dendritic cells, we determined the spectrum of phage K lytic activity against a panel of 36 diverse clinical S. aureus isolates including 25 MRSA and 11 MSSA strains using the efficiency of plating tests (Table 1). The strains were isolated from military patients with infections of traumatic and surgical wounds, urinary and respiratory tracts and septicemia. Phage K demonstrated a broad host range for both methicillin-resistant and methicillin-susceptible clinical isolates. Overall, 83\% (30/36) of strains were susceptible to phage $\mathrm{K}$. 


\subsection{Phage K Stability in PBS}

Since phage preparations intended for human cell studies were suspended in PBS (to minimize potential toxic effects on cells), which is a sub-optimal diluent for phage, we tested a short-term phage $\mathrm{K}$ stability at $4{ }^{\circ} \mathrm{C}$ in PBS including dialyzed and non-dialyzed phage stocks (Table 2). The results showed that the PBS stocks of phage $\mathrm{K}$ did not display a considerable reduction in titers at $4{ }^{\circ} \mathrm{C}$ at least for one month, while we used the phage preparations for cell culture experiments within two weeks.

Table 2. Stability of phage K suspended in PBS.

\begin{tabular}{cccccc}
\hline \multirow{2}{*}{ Phage K Stock } & \multicolumn{5}{c}{ Phage titer (PFU/mL) on: } \\
\cline { 2 - 6 } & Day 1 & Day 9 & Day 15 & Day 23 & Day 31 \\
\hline Non-dialyzed & $5 \times 10^{11}$ & $7 \times 10^{11}$ & $6 \times 10^{11}$ & $3 \times 10^{11}$ & $7 \times 10^{11}$ \\
Dialyzed & $7 \times 10^{11}$ & $5 \times 10^{11}$ & $6 \times 10^{11}$ & $4 \times 10^{11}$ & $3 \times 10^{11}$ \\
\hline
\end{tabular}

\subsection{Phage K Effects on Human Dendritic Cells}

We examined the potential inflammatory effects of the staphylococcal phage $\mathrm{K}$ in vitro using human monocyte-derived dendritic cells (MoDC). Two iterations of the experiment were conducted with different lots of human monocytes and different batches of phage. Immature MoDC were exposed to either PBS (negative control), phage K in PBS (100 PFU/cell), or TNF (positive activation control). The experiment showed a very limited effect of phage $\mathrm{K}$ on expression of a number of cytokines (IL-1 $\beta$, IL-2, IL-6, IL-8, IL-10, IL-12p70, IFN- $\gamma$, MCP-1, and RANTES) and surface markers (MHC I, MHC II, $\mathrm{CD} 80$, and CD86). The second experiment differed from the first one by a longer period of observation (four days instead of three) and included a second stock of phage $\mathrm{K}$ that had not gone through the extra purification by dialysis step. The results observed in the two experiments (see Figures 1 and 2) were consistent in terms of similar responses of the cells to phage $\mathrm{K}$ and the vehicle (PBS).

We observed a potent stimulation of expression of cytokines IL-6, IL-8, and RANTES by TNF-treated samples (positive control) and very weak responses to the $\mathrm{K}$ phage and PBS (Figure 1). Several cytokines tested (IL-1 $\beta$, IL-2, IL-10, IL-12p70, and IFN- $\gamma$ ) showed no measurable response in any experimental group (data not shown). Of the cytokines that showed measurable and consistent responses, there was no statistically significant difference between the PBS control and the phage $\mathrm{K}$ treated samples. There was a difference in overall magnitude of cytokine expression observed between the two iterations of the experiment, but this can likely be explained by the use of different lots of monocytes.

In addition to assessing the expression of cytokines, we assessed the maturation of the immature dendritic cells by examining their surface expression of co-stimulatory markers CD80 and CD86, as well as expression of the antigen-presenting markers MHC I and MHC II. In both experiments, expression of MHC I, MHC II, and CD86 was increased by TNF exposure relative to PBS negative controls at one or more timepoints tested, but phage K-treated groups displayed expression profiles similar to the PBS control (Figure 2). CD80 expression could not be assessed from the first experiment due to poor staining, but during the second experiment, it had a similar profile, with expression in the phage K-treated group paralleling the PBS control (Figure S1). 

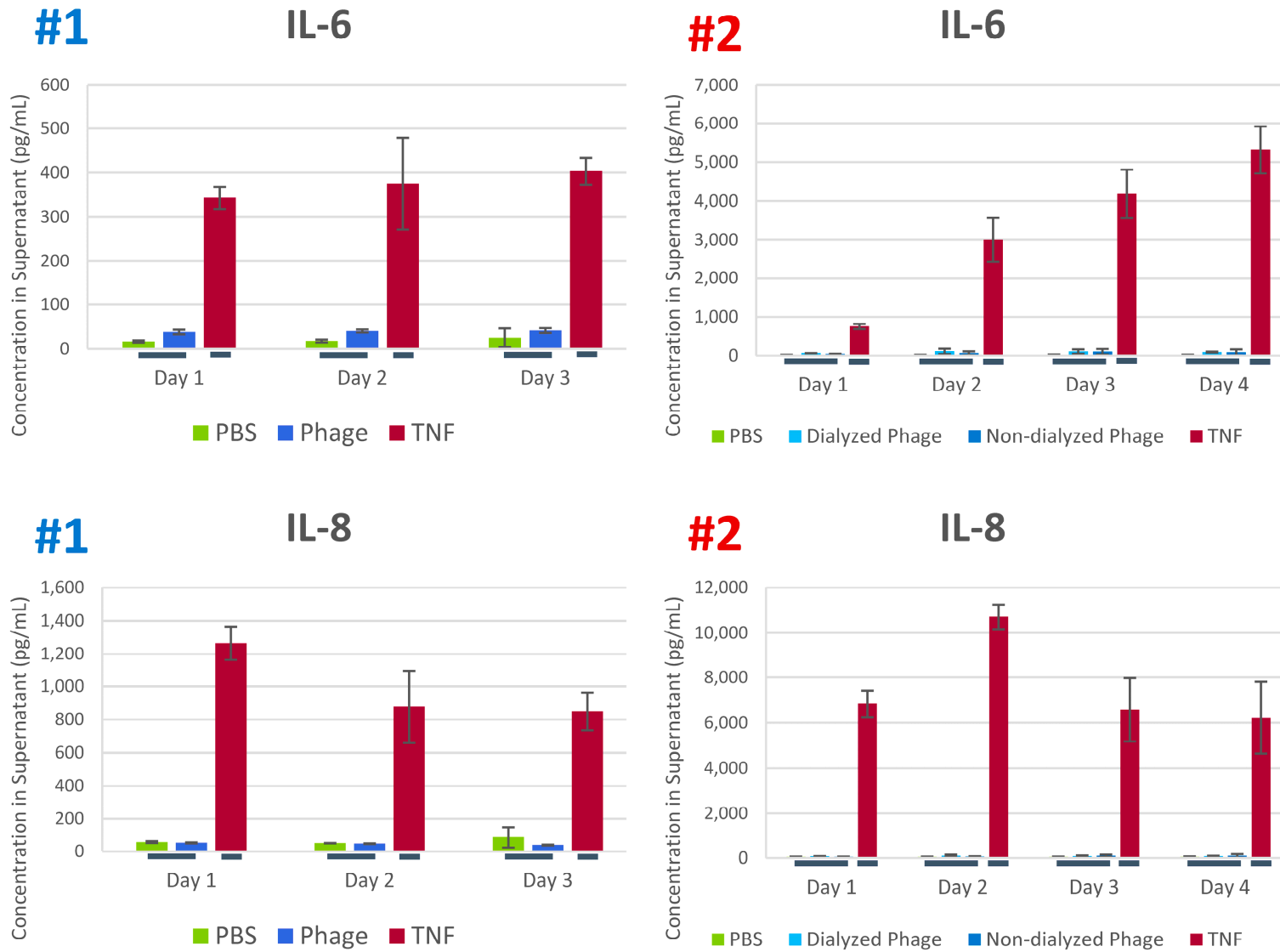

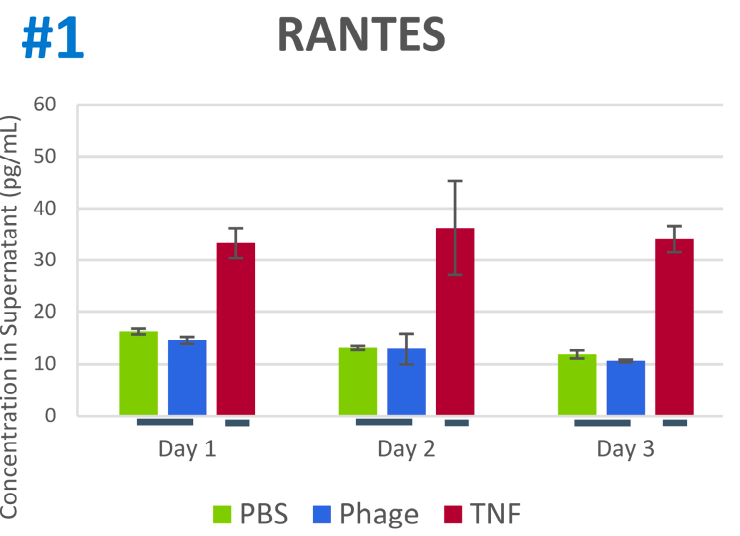

(a)
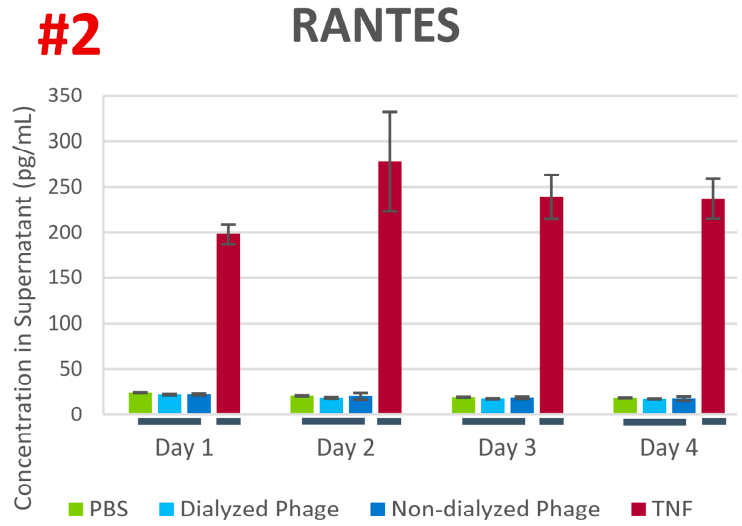

(b)

Figure 1. Examples of expression of cytokines IL-6, IL-8 and RANTES in response to phage K, PBS (negative control) and TNF (positive control) in experiments \#1 (a) and \#2 (b). Tukey grouping indicated by lines under bar graphs. $p$ values can be found in Supplemental Tables. 

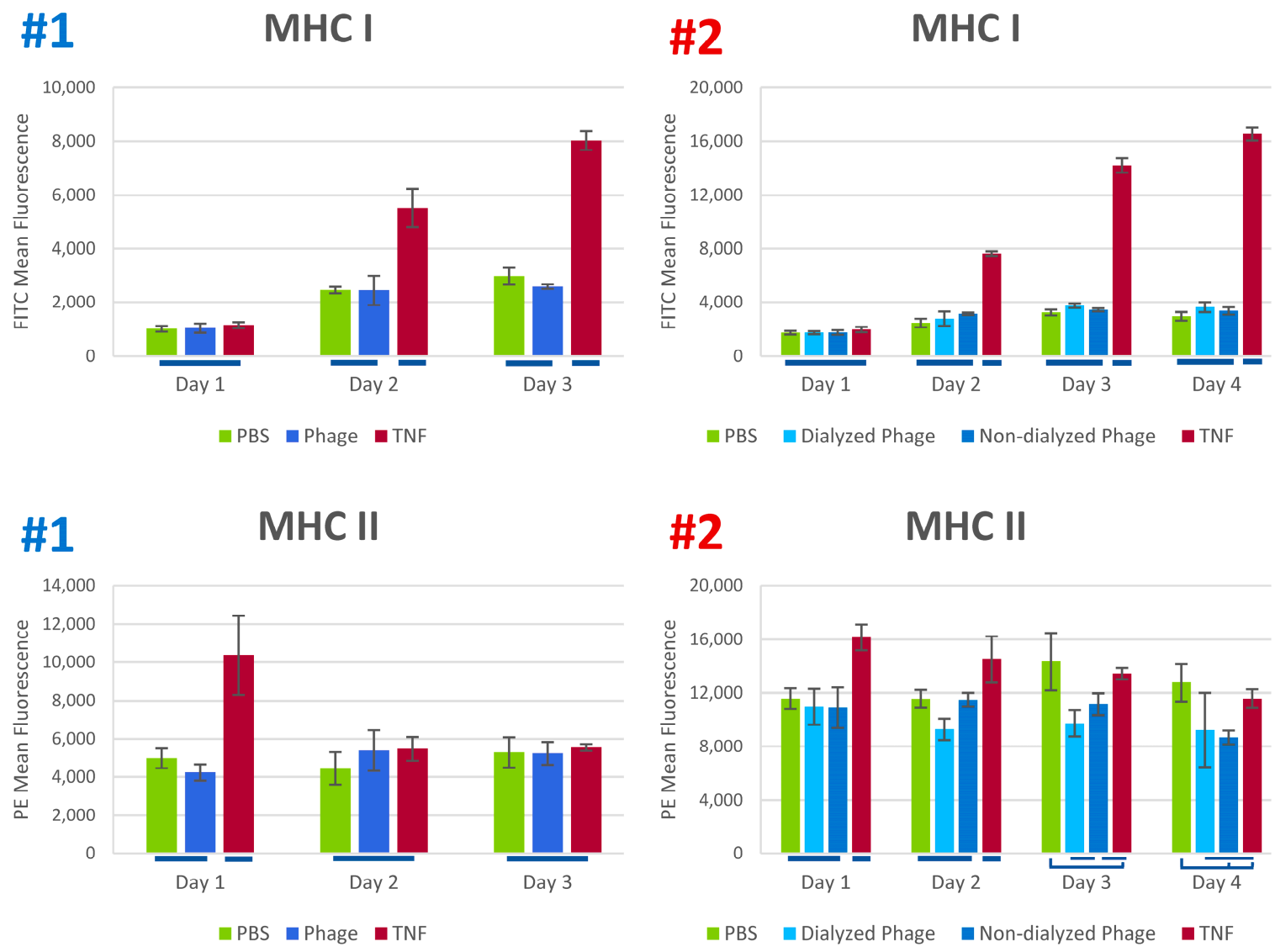

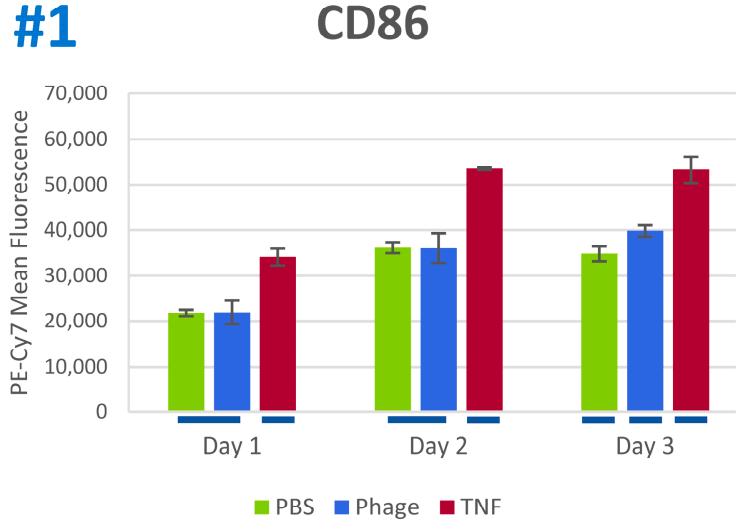

(a)

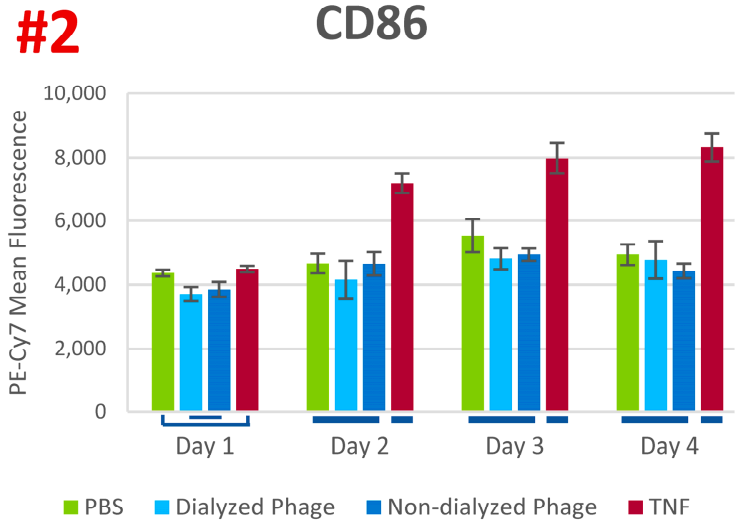

(b)

Figure 2. Examples of expression of antigen-presenting and costimulatory surface markers (MHC I, MHC II and CD86) in response to phage K, PBS (negative control) and TNF (positive control) in experiments \#1 (a) and \#2 (b). Tukey grouping indicated by lines under bar graphs. $p$ values can be found in Supplemental Tables.

\section{Discussion}

Staphylococcal phage K was isolated around 90 years ago [35] and belongs to the family Myoviridae, sub-family Spounavirinae and the genus of Twort-like phages [36]. This phage has been shown to lyse from $47 \%$ [37] to $84 \%$ [38] of S. aureus strains and was able to expand its host range after exposure to phage-resistant cultures [39]. Phage $\mathrm{K}$ alone [40], in the mix with another phage [41] or phage $\mathrm{K}$ modified variants [42] demonstrated significant degradation of biofilms in vitro. In another study, phage K efficiently dispersed $S$. aureus biofilms in central venous catheters in a rabbit model [43]. 
Phage $\mathrm{K}$ also prevented abscess formation in rabbits [44]. Our results on phage $\mathrm{K}$ host range for 36 clinical isolates from military patients $(83 \%)$ were very similar to those of Kelly et al. [38] obtained for 180 S. aureus isolates from clinical samples and dairy products $(84 \%)$.

The results of our cell culture experiments suggest that phage $K$ had little to no effect on the expression of most cytokines and activation markers tested. Similar data that show the lack of cytokine response in vitro in human cells and in vivo in a mouse model have been published for $E$. coli phage $\mathrm{T} 4$ and its head proteins [13]. None of three E. coli O157:H7 phages changed cytokine levels after oral administration to mice [14].

Our data also suggest that the phage preparations used in this study were sufficiently purified from pathogen-associated molecular patterns of $S$. aureus such as peptidoglycan, lipoteichoic acid and lipoproteins, potent activators of innate immune system that have been shown to enhance the production of cytokines by human dendritic cells [45].

Given that dendritic cells are potent antigen-presenting cells and messengers between the innate and the adaptive immune systems, our reproducible data suggest that staphylococcal phage K likely does not independently initiate an inflammatory reaction or may have a very limited impact. A single phage species may not be representative of other phages, so further investigations should be conducted to establish whether other phages have a different impact. Also, due to natural variations in immune reactions across different patients, this type of study should be conducted with a greater number of donor samples to establish reproducibility across a wider population.

Supplementary Materials: The following are available online at http:/ /www.mdpi.com/1999-4915/10/11/617/ s1, Figure S1: CD80 Expression during experiment \#2. Supplemental Tables: ANOVA $p$ values and Welch's paired $t$-test $p$ values for Experiments 1 and 2 .

Author Contributions: Conceptualization, H.R.F., A.L.R., M.P.N., and A.A.F.; Methodology, H.R.F., Y.H. and A.A.F.; Formal Analysis, H.R.F., Y.H. and A.A.F.; Resources, A.L.R., M.P.N. and A.A.F.; Writing-Original Draft Preparation, H.R.F. and A.A.F.; Writing-Review \& Editing, H.R.F., M.P.N. and A.A.F.; Supervision, M.P.N.; Project Administration, A.L.R., M.P.N. and A.A.F.; Funding Acquisition, A.L.R. and M.P.N.

Funding: This research was funded by US Defense Health Program, grant number W0232_17_WR.

Acknowledgments: Material has been reviewed by the Walter Reed Army Institute of Research. There is no objection to its presentation and/or publication. The opinions or assertions contained herein are the private views of the author, and are not to be construed as official, or as reflecting true views of the Department of the Army or the Department of Defense. We thank Yuanzhang Li for his help in statistical analysis.

Conflicts of Interest: The authors declare no conflict of interest.

\section{References}

1. Tong, S.Y.; Davis, J.S.; Eichenberger, E.; Holland, T.L.; Fowler, V.G., Jr. Staphylococcus aureus infections: Epidemiology, pathophysiology, clinical manifestations, and management. Clin. Microbiol. Rev. 2015, 28, 603-661. [CrossRef] [PubMed]

2. Hiramatsu, K.; Katayama, Y.; Matsuo, M.; Sasaki, T.; Morimoto, Y.; Sekiguchi, A.; Baba, T. Multi-drug-resistant Staphylococcus aureus and future chemotherapy. J. Infect. Chemother. 2014, 20, 593-601. [CrossRef] [PubMed]

3. Lister, J.L.; Horswill, A.R. Staphylococcus aureus biofilms: Recent developments in biofilm dispersal. Front. Cell. Infect. Microbiol. 2014, 4, 178. [CrossRef] [PubMed]

4. Kaźmierczak, Z.; Górski, A.; Dabrowska, K. Facing antibiotic resistance: Staphylococcus aureus phages as a medical tool. Viruses 2014, 6, 2551-2570. [CrossRef] [PubMed]

5. Nobrega, F.L.; Costa, A.R.; Kluskens, L.D.; Azeredo, J. Revisiting phage therapy: New applications for old resources. Trends Microbiol. 2015, 23, 185-191. [CrossRef] [PubMed]

6. Weber-Dąbrowska, B.; Jończyk-Matysiak, E.; Żaczek, M.; Łobocka, M.; Łusiak-Szelachowska, M.; Górski, A. Bacteriophage procurement for therapeutic purposes. Front. Microbiol. 2016, 7, 1177. [CrossRef] [PubMed]

7. Górski, A.; Międzybrodzki, R.; Weber-Dąbrowska, B.; Fortuna, W.; Letkiewicz, S.; Rogóż, P.; Jończyk-Matysiak, E.; Dąbrowska, K.; Majewska, J.; Borysowski, J. Phage therapy: Combating infections with potential for evolving from merely a treatment for complications to targeting diseases. Front. Microbiol. 2016, 7, 1515. [CrossRef] [PubMed] 
8. Górski, A.; Międzybrodzki, R.; Borysowski, J.; Dabrowska, K.; Wierzbicki, P.; Ohams, M.; Korczak-Kowalska, G.; Olszowska-Zaremba, N.; Łusiak-Szelachowska, M.; Kłak, M.; et al. Phage as a modulator of immune responses: Practical implications for phage therapy. Adv. Virus Res. 2012, 83, 41-71. [CrossRef] [PubMed]

9. Jończyk-Matysiak, E.; Weber-Dąbrowska, B.; Owczarek, B.; Międzybrodzki, R.; Łusiak-Szelachowska, M.; Łodej, N.; Górski, A. Phage-phagocyte interactions and their implications for phage application as therapeutics. Viruses 2017, 9, 150. [CrossRef] [PubMed]

10. Górski, A.; Dąbrowska, K.; Międzybrodzki, R.; Weber-Dąbrowska, B.; Łusiak-Szelachowska, M.; Jończyk-Matysiak, E.; Borysowski, J. Phages and immunomodulation. Future Microbiol. 2017, 12, 905-914. [CrossRef] [PubMed]

11. Mirzaei, M.K.; Haileselassie, Y.; Navis, M.; Cooper, C.; Sverremark-Ekström, E.; Nilsson, A.S. Morphologically distinct Escherichia coli bacteriophages differ in their efficacy and ability to stimulate cytokine release in vitro. Front. Microbiol. 2016, 7, 437. [CrossRef]

12. Dufour, N.; Henry, M.; Ricard, J.-D.; Debarbieux, L. Commentary: Morphologically distinct Escherichia coli bacteriophages differ in their efficacy and ability to stimulate cytokine release in vitro. Front. Microbiol. 2016, 7, 1029. [CrossRef] [PubMed]

13. Miernikiewicz, P.; Dabrowska, K.; Piotrowicz, A.; Owczarek, B.; Wojas-Turek, J.; Kicielińska, J.; Rossowska, J.; Pajtasz-Piasecka, E.; Hodyra, K.; Macegoniuk, K.; et al. T4 phage and its head surface proteins do not stimulate inflammatory mediator production. PLoS ONE 2013, 8, e71036. [CrossRef] [PubMed]

14. Hong, Y.; Thimmapuram, J.; Zhang, J.; Collings, C.K.; Bhide, K.; Schmidt, K.; Ebner, P.D. The impact of orally administered phages on host immune response and surrounding microbial communities. Bacteriophage 2016, 6, e1211066. [CrossRef] [PubMed]

15. Bocian, K.; Borysowski, J.; Zarzycki, M.; Pacek, M.; Weber-Dąbrowska, B.; Machcińska, M.; Korczak-Kowalska, G.; Górski, A. The effects of T4 and A3/R bacteriophages on differentiation of human myeloid dendritic cells. Front. Microbiol. 2016, 7, 1267. [CrossRef] [PubMed]

16. Pajtasz-Piasecka, E.; Rossowska, J.; Duś, D.; Weber-Dabrowska, B.; Zabłocka, A.; Górski, A. Bacteriophages support anti-tumor response initiated by DC-based vaccine against murine transplantable colon carcinoma. Immunol. Lett. 2008, 116, 24-32. [CrossRef] [PubMed]

17. Miedzybrodzki, R.; Fortuna, W.; Weber-Dabrowska, B.; Górski, A. A retrospective analysis of changes in inflammatory markers in patients treated with bacterial viruses. Clin. Exp. Med. 2009, 9, 303-312. [CrossRef] [PubMed]

18. Miernikiewicz, P.; Kłopot, A.; Soluch, R.; Szkuta, P.; Kęska, W.; Hodyra-Stefaniak, K.; Konopka, A.; Nowak, M.; Lecion, D.; Kaźmierczak, Z.; et al. T4 phage tail adhesin gp12 counteracts LPS-induced inflammation in vivo. Front. Microbiol. 2016, 7, 1112. [CrossRef] [PubMed]

19. Wang, Z.; Zheng, P.; Ji, W.; Fu, Q.; Wang, H.; Yan, Y.; Sun, J. SLPW: A virulent bacteriophage targeting methicillin-resistant Staphylococcus aureus in vitro and in vivo. Front. Microbiol. 2016, 7, 934. [CrossRef] [PubMed]

20. Shiley, J.R.; Comfort, K.K.; Robinson, J.B. Immunogenicity and antimicrobial effectiveness of Pseudomonas aeruginosa specific bacteriophage in a human lung in vitro model. Appl. Microbiol. Biotechnol. 2017, 101, 7977-7985. [CrossRef] [PubMed]

21. Pincus, N.B.; Reckhow, J.D.; Saleem, D.; Jammeh, M.L.; Datta, S.K.; Myles, I.A. Strain specific phage treatment for Staphylococcus aureus infection is influenced by host immunity and site of infection. PLoS ONE 2015, 10, e0124280. [CrossRef] [PubMed]

22. Barfoot, R.; Denham, S.; Gyure, L.A.; Hall, J.G.; Hobbs, S.M.; Jackson, L.E.; Robertson, D. Some properties of dendritic macrophages from peripheral lymph. Immunology 1989, 68, 233-239. [PubMed]

23. Kaźmierczak, Z.; Piotrowicz, A.; Owczarek, B.; Hodyra, K.; Miernikiewicz, P.; Lecion, D.; Harhala, M.; Górski, A.; Dąbrowska, K. Molecular imaging of T4 phage in mammalian tissues and cells. Bacteriophage 2014, 4, e28364. [CrossRef] [PubMed]

24. Jończyk-Matysiak, E.; Łusiak-Szelachowska, M.; Kłak, M.; Bubak, B.; Międzybrodzki, R.; Weber-Dabrowska, B.; Żaczek, M.; Fortuna, W.; Rogóż, P.; Letkiewicz, S.; et al. The effect of bacteriophage preparations on intracellular killing of bacteria by phagocytes. J. Immunol. Res. 2015, 2015, 482863. [CrossRef] [PubMed]

25. Weber-Dabrowska, B.; Zimecki, M.; Mulczyk, M.; Górski, A. Effect of phage therapy on the turnover and function of peripheral neutrophils. FEMS Immunol. Med. Microbiol. 2002, 34, 135-138. [CrossRef] [PubMed] 
26. Roach, D.R.; Leung, C.Y.; Henry, M.; Morello, E.; Singh, D.; Di Santo, J.P.; Weitz, J.S.; Debarbieux, L. Synergy between the host immune system and bacteriophage is essential for successful phage therapy against an acute respiratory pathogen. Cell Host Microbe. 2017, 22, 38-47. [CrossRef] [PubMed]

27. Capparelli, R.; Parlato, M.; Borriello, G.; Salvatore, P.; Iannelli, D. Experimental phage therapy against Staphylococcus aureus in mice. Antimicrob. Agents Chemother. 2007, 51, 2765-2773. [CrossRef] [PubMed]

28. Broxmeyer, L.; Sosnowska, D.; Miltner, E.; Chacón, O.; Wagner, D.; McGarvey, J.; Barletta, R.G.; Bermudez, L.E. Killing of Mycobacterium avium and Mycobacterium tuberculosis by a mycobacteriophage delivered by a nonvirulent mycobacterium: A model for phage therapy of intracellular bacterial pathogens. J. Infect. Dis. 2002, 186, 1155-1160. [CrossRef] [PubMed]

29. Filippov, A.A.; Sergueev, K.V.; He, Y.; Huang, X.Z.; Gnade, B.T.; Mueller, A.J.; Fernandez-Prada, C.M.; Nikolich, M.P. Bacteriophage therapy of experimental bubonic plague in mice. Adv. Exp. Med. Biol. 2012, 954, 337-348. [CrossRef] [PubMed]

30. Dąbrowska, K.; Miernikiewicz, P.; Piotrowicz, A.; Hodyra, K.; Owczarek, B.; Lecion, D.; Kaźmierczak, Z.; Letarov, A.; Górski, A. Immunogenicity studies of proteins forming the T4 phage head surface. J. Virol. 2014, 88, 12551-12557. [CrossRef] [PubMed]

31. Bruttin, A.; Brüssow, H. Human volunteers receiving Escherichia coli phage T4 orally: A safety test of phage therapy. Antimicrob. Agents Chemother. 2005, 49, 2874-2878. [CrossRef] [PubMed]

32. Łusiak-Szelachowska, M.; Zaczek, M.; Weber-Dabrowska, B.; Międzybrodzki, R.; Kłak, M.; Fortuna, W.; Letkiewicz, S.; Rogóż, P.; Szufnarowski, K.; Jończyk-Matysiak, E.; et al. Phage neutralization by sera of patients receiving phage therapy. Viral Immunol. 2014, 27, 295-304. [CrossRef] [PubMed]

33. Żaczek, M.; Łusiak-Szelachowska, M.; Jończyk-Matysiak, E.; Weber-Dąbrowska, B.; Międzybrodzki, R.; Owczarek, B.; Kopciuch, A.; Fortuna, W.; Rogóż, P.; Górski, A. Antibody production in response to staphylococcal MS-1 phage cocktail in patients undergoing phage therapy. Front. Microbiol. 2016, 7, 1681. [CrossRef]

34. Łusiak-Szelachowska, M.; Żaczek, M.; Weber-Dabrowska, B.; Międzybrodzki, R.; Letkiewicz, S.; Fortuna, W.; Rogóż, P.; Szufnarowski, K.; Jończyk-Matysiak, E.; Olchawa, E.; et al. Antiphage activity of sera during phage therapy in relation to its outcome. Future Microbiol. 2017, 12, 109-117. [CrossRef] [PubMed]

35. Krueger, A.P. A method for the quantitative determination of bacteriophage. J. Gen. Physiol. 1930, 13, 557-564. [CrossRef] [PubMed]

36. Deghorain, M.; Van Melderen, L. The staphylococci phages family: An overview. Viruses 2012, 4, 3316-3335. [CrossRef] [PubMed]

37. Hsieh, S.E.; Lo, H.H.; Chen, S.T.; Lee, M.C.; Tseng, Y.H. Wide host range and strong lytic activity of Staphylococcus aureus lytic phage Stau2. Appl. Environ. Microbiol. 2011, 77, 756-761. [CrossRef] [PubMed]

38. Kelly, D.; McAuliffe, O.; Ross, R.P.; O'Mahony, J.; Coffey, A. Development of a broad-host-range phage cocktail for biocontrol. Bioeng. Bugs 2011, 2, 31-37. [CrossRef] [PubMed]

39. O'Flaherty, S.; Ross, R.P.; Meaney, W.; Fitzgerald, G.F.; Elbreki, M.F.; Coffey, A. Potential of the polyvalent anti-Staphylococcus bacteriophage K for control of antibiotic-resistant staphylococci from hospitals. Appl. Environ. Microbiol. 2005, 71, 1836-1842. [CrossRef] [PubMed]

40. Lungren, M.P.; Christensen, D.; Kankotia, R.; Falk, I.; Paxton, B.E.; Kim, C.Y. Bacteriophage K for reduction of Staphylococcus aureus biofilm on central venous catheter material. Bacteriophage 2013, 3, e26825. [CrossRef] [PubMed]

41. Alves, D.R.; Gaudion, A.; Bean, J.E.; Perez Esteban, P.; Arnot, T.C.; Harper, D.R.; Kot, W.; Hansen, L.H.; Enright, M.C.; Jenkins, A.T. Combined use of bacteriophage $\mathrm{K}$ and a novel bacteriophage to reduce Staphylococcus aureus biofilm formation. Appl. Environ. Microbiol. 2014, 80, 6694-6703. [CrossRef] [PubMed]

42. Kelly, D.; McAuliffe, O.; Ross, R.P.; Coffey, A. Prevention of Staphylococcus aureus biofilm formation and reduction in established biofilm density using a combination of phage $\mathrm{K}$ and modified derivatives. Lett. Appl. Microbiol. 2012, 54, 286-291. [CrossRef] [PubMed]

43. Lungren, M.P.; Donlan, R.M.; Kankotia, R.; Paxton, B.E.; Falk, I.; Christensen, D.; Kim, C.Y. Bacteriophage K antimicrobial-lock technique for treatment of Staphylococcus aureus central venous catheter-related infection: A leporine model efficacy analysis. J. Vasc. Interv. Radiol. 2014, 25, 1627-1632. [CrossRef] [PubMed] 
44. Wills, Q.F.; Kerrigan, C.; Soothill, J.S. Experimental bacteriophage protection against Staphylococcus aureus abscesses in a rabbit model. Antimicrob. Agents Chemother. 2005, 49, 1220-1221. [CrossRef] [PubMed]

45. Wu, X.; Xu, F. Dendritic cells during Staphylococcus aureus infection: Subsets and roles. J. Transl. Med. 2014, 12, 358. [CrossRef] [PubMed] 